\title{
ROLE OF SEA BREAM FISH P. PAGRUS (FAMILY: SPARIDAE) IN HARBORING SOME LARVAL ASCARIDOIDS (FAMILY: ANISAKIDAE) IN CAIRO GOVERNORATE, EGYPT
}

\author{
By \\ RANIA GAMAL TAHA
}

Department of Biological and Geological Sciences, Faculty of Education, Ain-Shams University, Cairo, Egypt (Email: Dr.Raniagamal_bio@yahoo.com)

\section{Abstract}

The study dealt with anisakid nematode larvae $\left(\mathrm{L}_{3}\right)$ in a commercially important marine fish Pagrus pagrus purchased from different fish markets at 3 localities: El-Matareya, El-Zaitoun and, Saray El-Kobba, Cairo. Anisakid nematodes are zoonotic fish-borne parasites that may transmit to human by consuming raw fish containing the third stage larvae encapsulated in the fish muscles caused a serious disease Anisakidosis. The symptoms of that disease are nausea, diarrhea, vomiting and severe abdominal pain. Four species of $\mathrm{L}_{3}$ larvae were detected; Hysterothylacium sp., Raphidascaris sp., Contracaecum sp. and Terranova sp. Identification of the larvae depended basically upon the structure of the cephalic region, oesophogus shape, ventricular appendage, tail end and presence or absence of mucron. Two-hundred and thirtythree larvae were isolated from 80/140 (56.4\%) examined fish. The hosts were collected from November 2019 to April 2020. Larvae were measured in relation to host's weight, sex and infection prevalence. The results statistically showed that larvae prevalence and intensity were varied significantly in relation to host's sex and weight.

Key words: Third-stage larvae, Anisakidae, Pagrus pagrus, Fish-borne zoonoses

\section{Introduction}

Anisakiasis (Anisakidosis) is a fish-borne zoonotic parasite with larval stages of the ascaridoid nematodes belonging to family Anisakidae and probably Raphidascarididae. The Anisakids have two different hosts in life cycles: 1- Vertebrates including aquatic mammalians, birds, reptiles, and fish as definitive hosts. 2- Aquatic invertebrates and fish as paratenic or intermediate hosts (Murrell and Fried, 2007). The nematodes are transmitted to fish by microcrustaceans or any aquatic invertebrates and within the fish larvae changed to the third-stage larvae (Oshima, 1972). It may be transmitted several times from fish to fish before reaching the final host invading various tissues and organs as digestive canal, gonads, somatic musculature, liver, blood vessels, fins and eyes (Moravec, 1994; Dezfuli et al, 2007). The common sea bream $P$. pagrus (Linnaeus, 1758) was one of the most important and marketable food-fish. It lives in shallow water of Atlantic Ocean and the Mediterranean Sea. Severe inflammatory reactions, tissue deformation, cellular infiltration, nodules in the serosa of intestine and hemorrhage resu- lted from anisakids larvae infection (Marci et al, 2010; Levsen and Berland, 2012). Few histopathological studies on $P$. pagrus infected with Anisakis larvae are available: Eiras and Rego (1987) found a reduction in size of liver and spleen of infected fish. The fishborne parasitic zoonoses were limited to populations who live in the Far East Developing Countries for increasing international markets improved transportation systems and demographic changes such as population movements (Chai et al, 2005). Yet, zoonoses were responsible for large numbers of human infections worldwide. The knowledge of public health significance of zoonoses, their relations to cultural traditions, poverty, environmental degradation, and no control ways increased (WHO, 2004). Human is an accidental host in the life cycle acquire the anisakid infection by consuming row fish or seafood infected with larval stages in the flesh, viscera or body cavity (Audicana and Kennedy, 2008). Within human body, the nematodes never develop to adult, but penetrate the alimentary tract and associated organs causing severe pathological effects involved gastrointestinal disorders, vomiting, na- 
usea and allergic re-actions (Murrell and Fried, 2007). During the past three decades about 20.000 cases of zoonotic anisakidosis were worldly reported (Hochberg and Hamer, 2010). The increased human infection was attributed to high distribution of anisakid in almost all oceans and sea, increase in populations conservation measures, human migratory movements and globalization and the use of faster cooking tools a microwave (Audicana et al, 2003).

Ascaridoid nematode larvae from fish and cephalopods by Levsen et al. (2005), they detected Anisakis simplex larvae in the North Atlantic marine fishes. Al-Zubaidy (2010) from Red Sea fishes in Yemen Coast. Soares et al. (2014) detected 24 larvae of anisakid species: Contracaecum, Hysterothylacium, Raphidascaris from 7 fish out of 36 of $P$. pagrus in Rio de Janeiro, Brazil. Chen et al. (2018) detected third stage larvae of anisakid from Conger myriaster in China. Dadar et al. (2016) reported anisakis type III from some fish species in Persian Gulf. In Egypt, there were few reports about fish anisakid larva. Abdou (2005) identified Terranova sp. from Red Sea fishes. Abo-Mazyd et al. (2005) reported zoonotic anisakid in Fayoum Governorate. Rizk et al. (2015) reported it some marine fish in Damietta. Morsy et al. (2015) recorded three juvenile nematodes: Anisakis sp. type П, Hysterothylacium patagnense and Echinocephalus overstreeti from Saurida undosquamis in the Red Sea. Younis et al. (2017) found Contracaecum larva from teleostean species in Lake Nasser.

Anisakis sp., Raphidascaris and Terranova type 1 were identified as the major causative agents of human anisakiasis, genus Anisakis included nine species; 2 species of Anisakis simplex complex: A. simplex sensustricto (s.s) and $A$. pegreffii were associated with human infections (Audicana and Kennedy, 2008). Genus Hysterothylacium Ward and Magath, 1917 comprised more than 50 species of nematodes of teleost fish whereas larval stages live in various tissues of fish species and in $>100$ invertebrates of differ- ent phyla (Deardorff and Overstreet, 1980). Eiras and Rego (1987) in Brazil reported them as adult worm in liver of $P$. pagrus.

The present study aimed to determine occurrence, prevalence, and mean intensity of anisakid nematode larvae in a frequently consumed important zoonotic fish $P$. pagrus collected from different areas in Cairo.

\section{Materials and Methods}

Collection of specimens: Fish specimens $(\mathrm{n}=140)$ of the common seabream or red porgy Pagrus pagrus (Family: Sparidae) were collected from different fish markets at three localities; El-Matareya, El-Zaitoun and, Saray El-Qobba at Cairo, Egypt during the period from November 2019 to April 2020. Fishes were identified (Burgees et al, 2000; Schultz 2003). Weight and length of each one ranged from $35.5-75 \mathrm{gm}$ by $14.6-18.8 \mathrm{~cm}$ respectively. Fishes were differentiated to sex from outward confirmed to be 50 males \& 90 females. They were dissected to the internal organs such as digestive canal, liver, kidney, heart and gonads. Then, they washed very well in physiological solution $0.7 \%$ $\mathrm{NaCl}$. Alimentary canal was removed, sectioned into its main parts (stomach, small and large intestine). Internal organs and body cavity were examined for nematode larvae. Isolated larvae were counted, washed several times in saline solution, fixed in $7 \%$ warm formalin for $24 \mathrm{hrs}$, then cleared and mounted by lactophenol for morphological study. Specimen measurement was an important feature. Systematic characters were identified based on documented Keys (Cannon, 1977; Al-Zubaidy, 2010; Shamsi et al, 2018). Photomicrographs were done with a digital camera microscope and drawn using a camera Lucida. All measurements were in millimeters unless otherwise stated. Mean measurements were included with range in parentheses.

Statistical analysis: SPSS version-19.0 soft ware was used to data analysis. Nonparametric Spearman test was used to find the correlation between host's weight and infection intensity. Independent samples T-test 
and Chi-Square test correlated between intensity and prevalence of males and females.

\section{Results}

Seventy-nine $(56.4 \%)$ out of 140 fish $P$. pagrus were found infected with 233 thirdstage larvae. Larvae were isolated from body cavity as attached to the mesenteries of digestive canal. Total parasite abundance was 1.66. The larvae were identified as; Hysterothylacium sp. $(\mathrm{n}=112)$, Contracaecum sp. $(\mathrm{n}=36)$, Raphidascaris $\mathrm{sp} .(\mathrm{n}=68)$, and five larvae were Terranova sp. (Dia. 1).
Total mean intensity of nematodes (number of larvae per host) $=1.66 \pm 1.94$. The parasite abundance $=2.95$. SDE (standard error $)=0.16$, Variance $=3.7$, Range $=11$. Mean intensity was higher $2.3 \pm 1.87$ in males than $1.3 \pm 1.9$ in females of the infected fish (Tab. 2). Prevalence of infection in males was higher (70\%) than in females (48.9). Chi-Square test was used to analyze the correlation between the infection and the sex of the host. Data showed a high significant difference between them $\mathrm{P}<0.01$ (Tab. 3).

Table 1: Number of infections in male and female fish

\begin{tabular}{|c|c|c|c|}
\hline \multirow{2}{*}{ Count } & \multicolumn{3}{|c|}{ Infection } \\
\cline { 2 - 4 } & Infected & Non-infected & Total \\
\hline Male & 35 & 15 & 50 \\
\hline Female & 44 & 46 & 90 \\
\hline Total & 79 & 61 & 140 \\
\hline
\end{tabular}

Table 2: Prevalence and mean intensity of infection in both sexes

\begin{tabular}{|c|c|c|c|c|c|c|c|c|}
\hline Sex & No. & P\% & Mean & Std. Deviation & Std. Error & Variance & Median & Range \\
\hline Male & 50 & 70 & 2.30 & 1.876 & 0.265 & 3.5 & 2 & 6 \\
\hline Female & 90 & 48.9 & 1.31 & 1.905 & 0.201 & 3.63 & 0.0 & 11 \\
\hline
\end{tabular}

Table 3: Chi-Square Test

\begin{tabular}{|c|c|c|c|} 
Pearson Chi-Square & Value & df & Asymp. Sig-(2-sided) \\
\cline { 2 - 4 } & 5.826 & 1 & 0.016 \\
\hline
\end{tabular}

Table 4: Independent samples test relation between intensity of infection and host's sex

\begin{tabular}{|l|l|l|l|l|l|l|l|}
\hline \multirow{2}{*}{ Intensity } & \multicolumn{2}{|l|}{ Variances equality } & \multicolumn{4}{l|}{ t-test for Equality of Means } \\
\cline { 2 - 8 } & $\mathrm{F}$ & Sig. & $\mathrm{t}$ & $\mathrm{df}$ & Sig. (t-tailed) & Mean Difference & Std. Error Difference \\
\hline Equal variances assumed & \multirow{3}{*}{1.149} & \multirow{2}{*}{.286} & 2.958 & 138 & 0.004 & .988 & 0.334 \\
\cline { 1 - 6 } & & 2.971 & 102.699 & 0.004 & .988 & 0.332 \\
\hline
\end{tabular}

The relationship between intensity of infection and host's sex was statistically analyzed by independent samples t-test. The results showed that males have higher significant intensity than females $\mathrm{P}<0.004$ (Tab. 4). Fishes weight ranged from 35.5 to $75 \mathrm{gm}$. Prevalence of infection was higher in small sizes than larger ones in both males and females. Statistical analysis (Non-
Parametric Spearman Test) ensured a significant correlation at the 0.01 level (2tailed) between infection rate and the host size. Independent samples t-test was used to analyze the correlation and showed that a negative relationship between the weight of the host and infection as the infection increases in small weights of hosts than in the larger weights (Tab.5).

Table 5: Independent samples t-test showed relation between host weight and infection

\begin{tabular}{|l|l|l|l|l|l|l|l|}
\hline \multirow{2}{*}{ Weight } & Variances equality & \multicolumn{1}{l|}{ t-test for Equality of Means } \\
\cline { 2 - 8 } & F & Sig. & t & df & Sig.(tailed) & Mean Difference & Std. Error Difference \\
\hline Equal variances assumed & 1.406 & .238 & -12.907 & 138 & .000 & $-16.57159-$ & 1.283 \\
\hline Equal variances not assumed & & & -12.722 & 121.363 & .000 & $-16.57159-$ & 1.302 \\
\hline
\end{tabular}

Hsyterothylacium sp. (Ward and Magath, 1917) Family: Raphidascarididae: Small to medium in size, whitish color, total length $5.023 \pm 0.136(4.7-5.2)$ by $0.14 \pm 0.01$ wide (0.13-0.15), cuticle lightly striated longitudinally and transversely striated posteriorly. Three prominent lips, lip length $0.019 \pm 0.005$
(0.014-0.025), Nerve ring $0.23 \pm 0.028$ (0.210.25 ) from anterior end, excretory pore at ventral side immediately behind nerve ring level. Muscular oesophogus $0.75 \pm 0.12$ long (0.64-0.88) by $0.05 \pm 0.01$ wide $(0.04-0.06)$, ventricular appendix $0.503 \pm 0.07$ long $(0.42$ $0.56)$ by $0.057 \pm 0.009$ wide $(0.05-0.07)$. 
Ventriculus present between muscular oesophogus, appendage measured $0.05 \pm 0.01$ long (0.04-0.06). Intestinal caecum longer and wider than ventricular appendage, gonads as filament-like structure \& vulva not visible, Anus located at 0.07士-0.01 (0.060.08 ) from posterior extremity. Tail conical shaped with 2 developed caudal papillae (Figs. A, B, \& 1-4).

Contracaecum sp. Railliet and Henry, 1912; Family: Anisakidae: White in color and small sized body, $4.48 \pm 0.46$ long (4.05$5.1)$ by $0.18 \pm 0.02$ wide $(0.17-0.22)$. Cuticle transversely striated par at posterior body part. Mouth triangular surrounded by three inconspicuous lips 1 dorsal and 2ventrolateral, each lip measures $0.013 \pm 0.0026$ long (0.01-0.02), Cephalic capsule $0.04 \pm 0.01$ long (0.03-0.05). Nerve ring measured $0.22 \pm$ $0.04(0.17-0.25)$ from anterior extremity and oesophogus $1.33 \pm 0.2$ long (1.1-1.5). Ventricular appendix measured $0.57 \pm 0.07$ long (0.52-0.65), Ventriculus $0.06 \pm 0.01$ long (0.05-0.07). Anus measured $0.1 \pm 0.015$ (0.09-0.12) from posterior end. Tail $0.15 \pm$ 0.01 long (0.14-0.16) with blunt end lacked a mucron and two caudal papillae at anus level (Figs. C-D \& 9-10).

Raphidascaris sp. Railliet and Henry, 1915: Family: Raphidascarididae: Medium sized larva, body length $5.7 \pm 0.45$ (5.186.23 ) by $0.14 \pm 0.017$ wide $(0.13-0.17)$, Muscular oesophogus $0.55- \pm 0.05$ long $(0.5-0.6)$ by $0.066 \pm 0.02$ wide $(0.05-0.09)$. Ventricullus $0.06 \pm 0.01$ long $(0.05-0.07)$, Ventricular appendix $0.4 \pm 0.027$ (0.37-0.42), Nerve ring $0.17 \pm 0.04$ from anterior extremity $(0.12$ 0.2 ). Anus measured $0.09 \pm 0.01$ from posterior end (0.08-0.1), Tail ends with sharp mucron $0.007 \pm 0.002$ (0.001) (Figs. E, F \& 5-8).

Terranova sp. Linton, 1901, Family: Anisakidae: Medium sized larva, body cylinder and thin, measured 5.17 \pm 0.8 long (4.5-6.3) by $0.16 \pm 0.01$ wide $(0.15-0.17)$. Cephalic capsule $0.05 \pm 0.015$ long (0.04-0.07), Lips inconspicuous with a prominent tooth on cephalic region extreme anterior end $\&$ with four small papillae: two dorsolateral \& two ventrolateral. Cuticle greatly transversely striated particularly on tail region. Muscular oesophogus measured $0.6 \pm-0.2$ long (range $0.4-0.8)$ by $0.06 \pm 0.01$ wide $(0.05-0.07)$, but glandular one $1.13 \pm 0.25$ long (range $0.9-1.4$ ) by $0.04 \pm 0.007$ (0.04-0.05) wide, Ventriculus measured $0.04 \pm 0.01$ (range 0.03-0.05), intestine long wider than oesophogus, and opens in anus by a short rectum. Gonads not developed, excretory pore measured $0.056 \pm$ $0.015(0.04-0.07)$ from anterior extremity, Tail annulated, measured $0.06 \pm 0.153(0.05$ 0.08) long (Figs. G-H \&11-12).

\section{Discussion}

The anisakids constitute the ascaridoids with an aquatic definite host (mammal, bird, reptile, \& fish) which transmission depended on water and involves aquatic invertebrate and fish as intermediate host (Anderson, 2000). At least 20 different genera of anisakids have been described. Hartwich (1974) defined one family only within (Anisakidae), with 3 subfamilies: Anisakidae; Geoziinae and Raphidascaridinae. Fagerholm (1991) divided Anisakids into 2 families: Anisakidae that included 2 subfamilies: Anisakinae (Contracaecinae) and Raphidascarididae. They were extensive distributed parasites in Europe (The United Kingdom, France, The Netherlands, Germany, Italy, \& Spain), Asia (Iran, Japan, \& Korea), Africa (Egypt) and Americas (Canada, Alaska, \& Hawaii) (Daddar et al, 2016).

The present study revealed 4 species of anisakid nematode third-stage larvae (Hysterothylacium sp., Raphidascaris sp. Contracaecum sp. and Terranova sp.) attached to the mesenteries of internal organs and encapsulated on the wall of the stomach and intestine of the Sea-Bream fish P. pagrus. There was a scarce information concerning distribution of these anisakids in fishes especially those have a commercial important and mostly consumed by human particularly in Egypt. In the present study, total infection rate was (56.4\%), higher than (19.4\%) reported by Soares et al. (2014) from P. pa- 
grus in State of Rio de Janeiro, Brazil. They detected 24 larval of Anisakid sp., Contracaecum sp., Hysterothylacium sp. and Raphidascaris sp. and higher than (34\%) by Shamsi et al. (2018) in Australia, than (21.05\%) by Rezk et al. (2015) in Damietta Governorate, Egypt. Also, it was higher than (33.7\%) by Debenedetti et al. (2019) in At-1antic and Mediterranean Regions; they reported that larvae were higher in viscera than musculature. But, Morsy et al. (2015) recorded 3 juvenile nematodes; Anisakis sp. type $\Pi, H$. patagonense and Echinocephalus overstreeti from Saurida undosquamis in the Red Sea $(75 \%)$ that was higher than that in the present study. The high prevalence levels of infection by $\mathrm{L}_{3}$ larvae was reported (Chen et al, 2018), they identified Anisakis pegreffii, A. typica, A. simplex and five species of Hysterothylacium and Raphidascaris sp. from Conger myriaster in China $(100 \%)$. The present result was distinctly less than $(100 \%)$ reported in Korea (Setyobudi et al, 2011) from Salmon fish. These variations between the present result and the other previous might be due to different factors as geographical region, size and age of the host, seasonal variations, feeding habits, type of water supply, and abundance of final host (Dione et al, 2014).

The present study showed that male was significantly more infected by anisakid larvae than female. These agreed with Aliyua and Solomon (2012), and may be due to the fact that males were known to be more sensitive to parasitic infection than females due testosterone hormone effect which may exert a decreased immune competency (Bichi and Yelwa, 2010). A negative significant was found between host's weight and prevalence of infection. High value of intensity was recorded in the small sized fishes than in the larger ones. This disagreed with Kassem et al. (2015). It could be explained by that the small fishes were more activity moving within aquatic environment consequently have long exposure time to be infected by feeding. The zoonotic fish-borne nematodes have an economic significance and growing global health concern (Shamsi et al, 2018), caused by accidental infection with Anisakis L3 larvae. Oshima (1972) stated that the ascaridoid nematode larvae were capable of invasion of man. Several countries where raw fish was commonly consumed suffered from infection as Korea, Japan Taiwan, Europe, South Africa and North America (Buchmann and Mehrdana, 2016). Thus, zoonoses problem was reliable global behavior and feasible control and prevention programs were a must (Chai et al, 2005). Anisakids infection affect fish by increasing the susceptibility to predation, decreasing host density, reducing marketability of fish mainly when larvae were located in muscles caused economical loss for fish industry (Angot and Brasseur, 1995). Genus Hysterothylacium Ward and Magath, 1917 (Anisakidae, Rhaphidascaridinae) parasitized the digestive system of marine teleosts in temperate and cold waters (Deardorff and Overstreet, 1980). The genus is characterized by oesophogus divided into anterior muscular part and posterior glandular part separated by valvular structure and by conical tail and caudal papillae. The present Hysterothylacium sp. size agreed with Navone et al. (1998) for H. aduncum from the mesenteries of fishes Engraulis anchoita and Merluccius hubbsi in the South West Atlantic, and with Moravec et al. (1985) from fishes in Japan.

In the present study, infection by L3 larva Hysterothylacium was high (48\%) than the other discovered larvae, and may be attributed to food habits of the host during ilife span (Navone et al, 1998). The occurrence of Contracaecum sp. Railliet and Henry, 1912 in the present fishes was (15.4\%), lower than $(35.6 .5 ; 82 \% ; 100 \%)$ from Oreochromis niloticus, Hydrocynus forskahlii and Lates niloticus respectively in Lake Nasser (Younis et al, 2017), than (23\%) by Moravec et al. (2016) who presented Contracaecum sp. for the first time from freshwater fish Sandelia capensis in South Africa. they stated to be with low pathogenicity. But, it 
was higher than $(0.14 \%)$ in Tilapia galilaea. Contracaecum $3^{\text {rd }}$ stage larva of the present study was morphologically similar to Contracaecum larval type II of Cannon (1977) from Queensland fishes and, in length, width and oesophogus. The third stage larva of Raphidascaris was $29.18 \%$ of all anisakid larvae in the present study. It was lower than (63\%) by Valtonen et al. (1994) from roach (Rutilus rutilus) in Finland. This genus is distinct by pointed tail (mucron), well-developed lips that bear double papillae without interlabia, and triangular mouth opening. It was described from marine and freshwater fish (Malta et al, 2020). Genus Terranova sp. was represented by the lowest infection rate $(2.14 \%)$ that was less than $(19 \%)$ by Abdou (2005) in Hurghada. It was distinct by a boring tooth and well developed mucron with strongly transversally striated posterior extremity, with high specificity to the final host and fish body cavity represented the most favorable medium for infection (Andrada et al, 2008).

In the present study, larva Terranova sp. was recorded from body cavity and mesenteries of P. pagrus as new host record. Shamsi and Suthar (2016) reported that all Terranova larvae cause zoonotic Pseudoterranvosis, they were similar in shape and cannot be distinguished by morphology. The variety of the larval infection in $P$. pagrus fish in the present study may be either due to the feeding habits of this host or abundance of definitive host in the collected area.

Anisakids were identified essentially due to some important taxonomical characters as cephalic region, the presence of boring tooth or lips, the presence or absence of mucron (caudal spine or cactus tail), position of excretory pore, length of ventriculus (Anderson, 2000; Shin and Jengo, 2002).

Some recommendations were in considered to avoid infection such as cooking fish by heating to $60^{\circ} \mathrm{C}$ for some minutes and freezing to $-20^{\circ} \mathrm{C}$ for $24 \mathrm{hr}$ enough to kill larvae (Wharton and Aalders, 2002). But, domestic freezers didn't provide a low homogenous temperature and thus, not able to inactivate larvae (Debenedetti et al, 2019). Albendazole ${ }^{\circledR} \&$ Thiabendazole ${ }^{\circledR}$ treated anisakid in man and herbs (Pacios et al, 2005) and Mir$\operatorname{azid}^{\circledR}$ (Abo Mazyad et al, 2004). Prevention, proper identification, and effective therapy dramatically improve the health and productivity of affected fish (Yanong, 2002).

\section{Conclusion}

The results revealed that the marine fish $P$. pagrus representing a proper environment for the harboring the anisakid third stage larvae.

\section{References}

Abdou, EN, 2005: Studies on the anisakid nematode juveniles infecting some red sea fishes in Egypt. J. Egy. Ger. Soc. Zool. 47, D:89-102.

Abo-Madyan, AA, Morsy, TA, Motawea, SM, Morsy, ATA, 2004: Clinical trial of Mirazid ${ }^{\mathbb{B}}$ in treatment of human fascioliasis in Ezbet ElBakly (Tamyia Center) Al-Fayoum Governorate. J. Egypt. Soc. Parasitol. 34, 3: 807-18.

Abo-Madyan, AA, Morsy, TA, Motawea, S M, El Garhy, MF, Massoud, AMA, 2005: Spot light survey on fresh-water snails of medical importance in Al Fayoum Governorate, Egypt. J. Egypt. Soc. Parasitol. 35, 1:49-58.

Al-Zubaidy, BA, 2010: Third-Stage larvae of Anisakis simplex (Rudolphi, 1809) in the Red Sea fishes, Yemen Coast. JKAU: Mari. Sci. 21, 1:95-112.

Aliyua, MD, Solomon, JR, 2012: The intestinal parasite of Clarias gariepinus found at lower us man dam, Abuja. Res. 4, 9:38-44.

Anderson, RC, 2000: Nematode parasites of vertebrates: Their development and transmission ( $2^{\text {nd }}$ ed.). Wallingford: CABI Publishing, $C A B$ International.

Andrada, DM, Galindez, JE, Estecondo, S, Tanzola, DR, 2008: Hepatic infection by Terranova sp. (Nematoda, Anisakidae) larvae in $S y$ mpterygia acuta (Chondrichthyes, Rajidae). Bull. Eur. Ass. Fish Pathol. 28, 4:144-9.

Angot, V, Brasseur, P, 1995: Les larvesd anisakides et leur incidence sur laqualite des poisons et produits de poisson. Revue de Med. Vet. 146: 791-804.

Audicana, MT, Kennedy, MW, 2008: Anisakis simplex: from obscure infectious worm to inducer of immune hypersensitivity. Clin. Microbial. Rev. 21:360-7. 
Audicana, MT, DelPoz, MD, Iglesias, R, Ubeira, FM, 2003: Anisakis simplex and Pseudoterranovadecipiens. In: R. Learmonth and MD. Milliotis (eds.), International Handbook of Foodborne Pathogens, $1^{\text {st }}$ edition. Marcel Dekker, New York.

Bichi, AH, Yelwa, SI, 2010: Incidence of piscine parasites on the gills and gastro-intestinal tract of Clarias Garie pinus (Teugels) at Bagauda fish farm, Kano, Bayero. J. Pure Appl. Sci. 3, 1:104-7.

Burgees, EW, Axelord, RH, Hunziker, ER, 2000: Atlas of Marine Aquarium Fishes: Published by TFH Publications, $3^{\text {rd }}$ edition.

Bushmann, K, Mehrdana, F, 2016: Effects of anisakid nematodes Anisakis simplex (s.1.), Pseudoterranova decipiens (s.l.) and Contracaecum osculatum (s.1.) on fish and consumer health. Food Water-brone Parasitol. 4:13-22. Cannon, GRL, 1977: Some larval Ascaridoids from South-Eastern Queensland marine fishes. Inter. J. Parasitol. 7:233-43.

Chai, JY, Murrell, KD, Lymbery, AJ, 2005: Fish-borne parasitic zoonoses: Status and issues. Int. J. Parasitol. 35:1233-54.

Chen, H, Zhang, L, Gibson, ID, Lu, L, Xu, Z, et al, 2018: Detection of ascaridoid nematodes parasites in the important marine food-fish Conger myriaster (Brevoort) (Anguilliformes: Congridae) from the Zhoushan fishery, China. Parasit. Vect. 11:274-9.

Deardorff, TL, Overstreet, RM, 1980: Review of Hysterothylacium and Iberingascaris (both previously Thynnascaris) (Nematoda: Anisakidae) from the northern Gulf of Mexico. Proceed. of the Biol. Soc. of Wash. 93, 4:1035-79.

Debenedetti, LA, Madrid, E, Trelis, M, Codes, JF, Gil-Gomez, F, et al, 2019: Prevalence and risk of Anisakid larvae in fresh fish frequently consumed in Spain: An overview. Fishes 4, 13. DOI:10.3390/ fishes 4010013.

Dezfuli, SB, Pironi, F, Shinn, PA, Manera, M, Giari, L, 2007: Histopathology and ultrastructure of Platichthys flesus naturally infected with Anisakis simplex s.l. larvae (Nematoda: Anisakidae). J. Parasitol. 93, 6:1416-23.

Dadar, M, Alborzi, A, Peyghan, R, Adel, M, 2016: Occurrence and intensity of anisakid nematode larvae in some commercially important fish species in Persian Gulf. Iran J. Parasitol. 11, 2:239-46.

Dione, EN, Diouf, M, Sarr, A, Fall, J, Tidiana, BC, 2014: Parasitic burden and pathologic effects of Anisakis spp. (Nematoda: Anisakinae, Anisakidae) and Contra-caecum spp. larvae (Nematoda: Anisakinae, Anisakidae) on Mugilids from Senegalese Estuaries. JBLS 5:2-8.

Eiras, JC, Rego, AA, 1987: The histopathology of Scomber japonicus infection by Nematobothrium scombri (Trematoda: Didymozo idae) and of larval anisakid nematode infections in the liver of Pagrus pagrus. Mem. Inst. Oswaldo Cruz 82, 2:155-9.

Fragerholm, HP, 1991: Systematic implications of male caudal morphology in ascaridoid nematode parasite. Syst. Parasitol. 19:215-28.

Hartwich, G, 1974: Keys to genera of Ascaridoidea. Anderson, RC, Chabaud, AG, Willmott, $\mathrm{S}$, eds, CIH keys to the nematode parasites of vertebrates (pp. 1-15). Farnham Royal: Commonwealth Agricultural Bureaux.

Hochberg, NS, Hamer, DH, 2010: Anisakidosis: Perils of the deep. Clin. Infect. Dis. 51: 806-12.

Levsen, A, Berland, B, 2012: Anisakis species. In: Woo, P.T.K. Buchmann, K. (Eds.), Fish Parasites, Pathobiology and Protection 18. CAB International.

Levsen, A, Lunestad, TB, Berland, B, 2005: Low detection efficiency of candling as a co-mmonly recommended inspection method for nematode larvae in the flesh of pelagic fish. J. Food Protec. 68, 4:828-32.

Malta, SL, Pavia, F, Tavares, REL, 2020: A new species of Raphidascaris (Nematoda: Raphidascarididae) infecting the fish Gymnogeophagus balzanii (Cichlidae) from the pantanal wetlands, Brazil and a taxonomic update of the subgenera of Raphidascaris based on molecular phylogeny and morphology. J. Helminthol. 94: e24. http://doi.org/10.1017/s0022149x18001153. Marci, F, Manganaro, M, Caristina, G, Busalacchi, B, Marino, F, 2010: Gastroscopic, laparoscopic and pathological findings in experimental anisakiasis in Sea bass. Rapp. Comm. Int. Mer. Medit. 39.

Moravec, F, 1994: Parasitic Nematodes of Freshwater Fishes of Europe. Kluwer, Dordrecht, The Netherlands.

Moravec, F, Nagasawa, K, Urawa, S, 1985: Some fish nematodes from fresh waters in Hokkaido, Japan. Folia Parasitol. 32:305-16.

Moravec, F, Rensburg, VJC, As, VLL, 2016: Larvae of Contracaecum sp. (Nematoda: Anisakidae) in the threatened freshwater fish Sandelia capensis (Anabantidae) in South Africa. 
Dis. Aqua. Organ. 120, 3:251-4.

Morsy, K, Bashtar, A, Mostafa, N, El-Deep, Thabet, S, 2015: New host records of three juveniles nematodes in Egypt: Anisakis sp. (Type II), Hysterothylacium patagonense (Anisakidae), and Echinocephalus overstreeti (Gnathostomatidae) from the greater lizard fish Saurida undosquamis of the Red Sea. Parasitol. Res. 114:1119-28.

Murrell, DK, Fried, B, 2007: World Class Parasites-Fish-Borne Parasitic Zoonoses. A Textbook; Springer Science Publisher, USA.

Navonne, GT, Sardella, NH, Timi, J, 1998: Larvae and adults of Hysterothylacium aduncum (Rudolphi, 1802) (Nematoda: Anisakidae) in fishes and crustaceans in the South West Atlantic. Parasit. 5:127-36.

Oshima, T, 1972: Anisakis and Anisakiasis in Japan and adjacent area. Progr. Med. Parasitol. Jpn. 4:301-93.

Pacios, E, Arias-Diaz, J, Zuloaga, J, Gonzalez-Amengol, J, Villarroel, P, et al, 2005: Albendazole for the treatment of anisakiasis ileus. Clin. Infect. Dis. 41, 12:1825-6.

Rezk, MM, El-Gohary, NH, Mohamed, AA, Abdel-Maksoud, AA, 2015: Role of some fish in harbouring zoonotic anisakid nematodes at Damietta Governorate, Egypt. https// www. Researchgate.net/publication/28883177.

Schultz, K, 2003: Field Guide to Saltwater Fish. $1^{\text {st }}$ edition, Published by Wiley.

Setyobudi, E, Jeon, CH, Lee, CH, Seong, KB, Kim, JH, 2011: Occurrence and identification of Anisakis spp. (Nematoda: Anisakidae) Isolated from Chum Salmon (Onchorhynchus keta) in Korea. Parasitol. Res. 108, 3:585-92.
Shamsi, S, Steller, E, Chen, Y, 2018: New \& known zoonotic nematode larvae within selected fish species from Queensland waters in Australia. Inter. J. Food Microbiol. 272:73-82.

Shin, HH, Jeng, MS, 2002: $H$. aduncum (Nematoda: Anisakidae) infecting a herbivorous fish, Siganus fuscescens, of Taiwanese Coast, Northwest Pacific. Zool. Stud. 41, 2:208-15.

Shamsi, S, Suthar, J, 2016: A revised method of examining fish for infection with zoonotic nematode larvae. Inter. J. of Food Microbiol. 227:13-6.

Soares, AI, Vieira, MF, Luque, LJ, 2014: Parasite community of Pagrus pagrus (Sparidae) from Rio de Janeiro, Brazil: evidence of temporal stability, Rev. Bras. Parasitol. Vet. 23:21623.

Valtonen, T, Haaparanta, A, Hoffmann, W, 1994: Occurrence and histological response of Raphidascaris acus (Nematoda: Ascaridoidia) in roach from four lakes differing in water quality. Inter. J. Parasitol. 24, 2:197-206.

Wharton, DA, Aalders, O, 2002: The response of Anisakis larvae to freezing. J. Helminthol. 76:363-8.

WHO, 2004: Report of Joint WHO/FAO workshop on food-borne trematode infections in Asia, Ha Noi, Vietnam, 26-28.

Yanong, EPR, 2002: Nematode (Roundworm) infection in fish. http://edis.ifas. ufl. edu.

Younis, EA, Saad, IA, Rabei, MJ, 2017: The occurrence of Contracaecum sp. larvae (Nematoda: Anisakidae) in four teleostean species from Lake Nasser, Egypt: morphological and molecular studies. J. Bas. Appl. Zool. 78:9. DOI: 10. 1186/s41936-4

Dia. 1: Prevalence of nematode larvae in the examined fishes

Fig. 1:A-H: Anterior and posterior extremities of Anisakid nematode larval morphotypes isolated from P. pagrus in Cairo, Egypt. A\&B, Hysterothylacium sp., C\&D, Contracaecum sp., E\&F, Rhaphidascaris sp. and G\&H, Terranova sp.

Fig. 2:1-12: Larval stages (L3) of nematodes. 1-4: Hysterothylacium sp. 5-8: Rhaphidascaris sp. 9-10: Contracaecum sp. and 11-12: Terranova sp. showed venterolateral lip (arrow), nerve ring (NV) ventriculus (V), rectal glands (RG), intestine (I), gonad (G). mucron (M), rectum (R), anus (star), caudal papillae (CD), boring tooth (thick arrow), transverse striations (TS). Scale bars $=0.01 \mathrm{~mm}$.

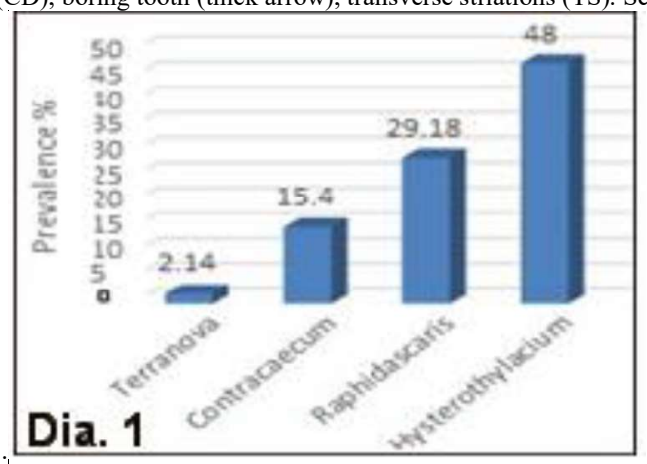



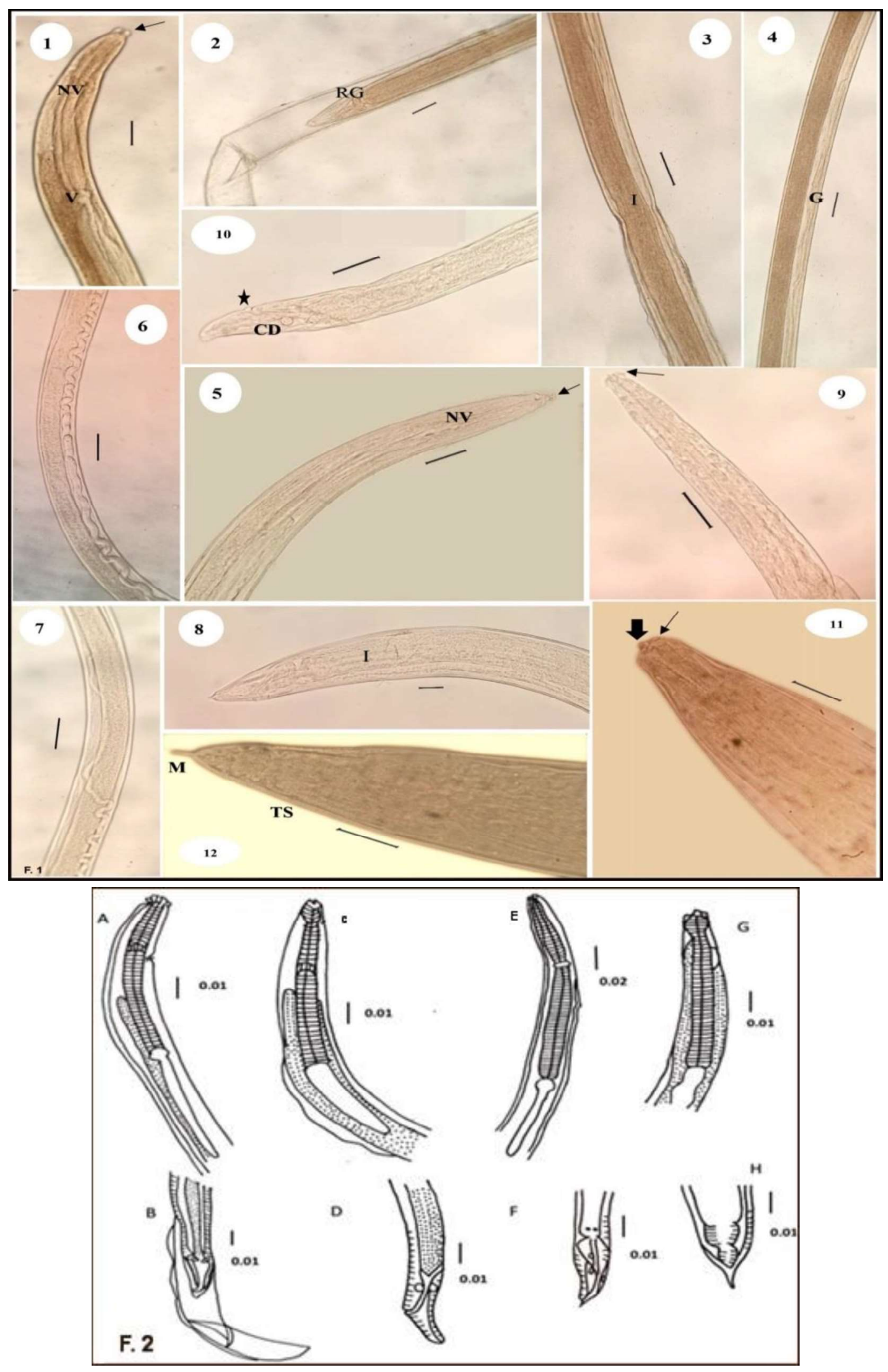